\title{
Association of pain between elastomeric and the kesling sparators in the orthodontic patients
}

\author{
Dr. Abhilasha Khanal' ${ }^{1}$ Dr. Manish Bajracharya ${ }^{2}$, Dr. Neesha Shrestha ${ }^{3}$ \\ 'Assistant Professor, ${ }^{2}$ Associate Professor, ${ }^{3}$ Orthodontist, \\ Dept. of Dentistry, Orthodontics and Dentofacial Orthopedics \\ National Academy of medical sciences, Bir Hospital \\ Corresponding author: Dr. Abhilasha Khanal; Email: abhilashakhanal@yahoo.com
}

ABSTRACT

Introduction: Pain may be experienced during the first 3-4 days of fixed Orthodontic appliance activation. The lesser the pain perceived by a patient, better the treatment outcome and the patient compliance. The post separator placement pain increases as soon as 4 hours and gradually increases over the next 24 hours which is worst at the day 2-4.

The Aim of the study is to find out the association of post separator placement pain in our population. Also, the study focuses on the use of dose Paracetamol $500 \mathrm{gms}$, by our patients in case of pain.

Materials and Method: Elastomeric separator was placed mesially and distally to the upper right first permanent molar(16) and the kesling separator was placed to the left first permanent molar(26) in 100 orthodontic patients . Patients were given a questionnaire that documented perceived pain, pain on chewing, pain affecting the daily life activities. The patient documented the intake of medication to reduce the pain, if at all. Two different Pain rating scales (PRS) along a line will be used to depict the pain perception. The subjects were asked to circle a spot on the line that they believed best represented the pain they perceived at that time. The evaluation of pain and documentation started on the 4th hour, 24th hrs, 2nd day, 3rd day, 4th day, 5th day, 6th day and the 7th day. Scores 1-3 will be considered as mild pain; $4-6$ will be moderate pain and 7-10 is considered to be the severe pain. At every time slot, the pain was documented, there was a spot where the patient has mentioned if he / she used the medication prescribed by the orthodontist.

Results: No association of Kesling separators with Pain on chewing, pain perception and pain affecting life at 4th hour, 24th hour, 2nd day, 3rd day, 4th day, 5th day, 6th day, 7th day post separator placement. Association of Medication with the post separator placement pain also is not significant.

Significant association of elastomeric separators with pain perception and pain affecting life at 4 th hour $(p=0.002$ \& $p=0.005)$, 24th hour $(p=0.002)$. Significant Association of Medication with the post separator placement pain also is significant at 4 th $(p=0.00)$ and 24 th hour $(p=0.02)$ of post separator placement.

Conclusion: There is a significant association of elastomeric separators with pain perception and pain affecting life at 4th hour, 24th hour. Significant Association of Medication with the post separator placement pain also is significant at 4th and 24th hour of post separator placement.

KEYWORDS: Elastomeric separator, Kesling separator, Medication, Pain

\section{INTRODUCTION}

Pain is an irksome experience, which differs with individuals. Pain is a physical experience, influenced by attitudes, beliefs, threshold, personality and mental stability. Painful sensation may be easily bearable to one while devastating for the other.
Pain may be experienced during the first 3-4 days of fixed Orthodontic appliance activation, during and post spacer placement, during the head gear use, post Orthognathic surgeries, Rapid palatal expansion, Temporary anchorage device (TAD) placement and the use of intraoral and extra oral elastics. ${ }^{1,2}$ 
The first step in Fixed Orthodontic treatment, the separators placement, should be effective and with less pain if not painless. The Orthodontic patients who experienced headache more frequently and who's experienced the episodes of pain even during their leisure reported more alteration in their everyday life due to pain. The model was also in line with the postsurgical patients. ${ }^{3}$

The lesser the pain perceived by a patient, better the treatment outcome and the patient compliance. The patients who were previously treated Orthodontically experienced less pain and showed an optimistic attitude. The pain experienced during the orthodontic separators insertion is known to be highly affected by the psychological factors such as the Pain catastrophizing..$^{4,5,6}$

The most effective method to control the pain induce by the spacer have been reported to the use of the nonsteroidal anti-inflammatory drugs (NSAIDs). The low doses of the NSAIDS don't hinder the inflammatory process and the tooth movement. Acetaminophen so far is the best remedy and significantly effective to the placebo in the post separator pain. ${ }^{7,8}$

The post separator placement pain increases as soon as 4 hours and gradually increases over the next 24 hours which is worst at the day 2-4, becomes as normal as the pre placement state within 5-7 days. ${ }^{9-11}$ Following the application of orthodontic force, the levels of RANKL and IL-17A tend to increase and so do the levels of Interleukin-1 $\beta$, substance $P$, and PGE2. These levels are seen to increase more in the females and thus the female might experience more pain after the separator placement. ${ }^{12,13}$

The Aim of the study is to find out the association of post separator placement pain in our population. Also, the study focuses on the use of dose Paracetamol $500 \mathrm{gms}$, by our patients in case of pain.

\section{MATERIALS AND METHODS}

Patients scheduled to have the fixed orthodontic treatment at the National Academy of health sciences, Bir Hospital, Kathmandu were requested to participate in our study on a voluntary basis. Ethical approval to conduct the study was approved from IRB, NAMS. In the case of minors the consent to participate in the study was obtained from their guardians. The patients aged from 16-30 were included in the study. All the patients underwent oral prophylaxis and the Plaque and the gingival index were recorded at the " 0 " and between " 0.1 to 1.0 " respectively in both the baseline, recall and at the day of separator placement. The participants were informed and the consent was signed before the process of separator placement.

Elastomeric separator was placed mesially and distally to the upper right first permanent molar $^{16}$ and the kesling spring made of 0.016 premium Australian wire was placed to the left first permanent molar $^{26}$ in 100 orthodontic patients divided equally between the (male and female) with the mean age of 23 years. After the separator placement, patients were given a questionnaire that documented perceived pain, pain on chewing, pain affecting the daily life activities. Also, the patient documented the intake of medication to reduce the pain, if at all. Two different Pain rating scales (PRS) along a line will be used to depict the pain perception. The subjects were asked to circle a spot on the line that they believed best represented the pain they perceived at that time. On the left end of the line, the phrase "no pain" was written, while on the right end, the phrase "worst possible pain" was written. The evaluation of pain and documentation started on the 4th hour, 24th hrs, 2nd day, 3rd day, 4th day, 5th day, 6th day and the 7th day. Two different PRS were used to portray the pain perception for two different kinds of separators. Scores 1-3 will be considered as mild pain; $4-6$ will be moderate pain and 7-10 is considered to be the severe pain. At every time slot, the pain was documented, there was a spot where the patient has mentioned if he / she used the medication prescribed by the orthodontist.

\section{Data Analysis}

The data will be analyzed using SPSS ${ }^{\circledR}$ Statistics, version 20 (International Business Machines Corporation, Armonk, New York, USA), and the level of significance was set at $\mathrm{P}<0.05$. Non Parametric analysis (Chi-square and fishers exact test) were done to signify the association of pain using elastomeric and Kesling separators in all the patients at $4 \mathrm{hrs}, 24 \mathrm{hrs}$, 2nd day, 3rd day, 4th day, 5th day, 6th day and the 7th day of separator placement. Also, the association of medication during the separation procedure was noted starting from the Day 1 to Day 7.

\section{Ethical consideration}

Ethical approval was taken from IRB (Ref. No1099), National Academy of medical sciences. Consent to start the orthodontic treatment and the consent of the subjects to be included in the study was taken before hand in English and as well as in Nepali. In case of a minor, the guardian and the witness's signature and in case of patients $>18$ years the patients and the witness's signature was mandatory. 


\section{RESULT}

Table 1: There is no association of Kesling separators with Pain on chewing, pain perception and pain affecting life at 4th hour, 24th hour, 2nd day, 3rd day, 4th day, 5th day, 6th day, 7th day post separator placement. Association of Medication with the post separator placement pain also is not significant.

\begin{tabular}{|c|c|c|c|c|c|}
\hline \multicolumn{2}{|c|}{ KESLING SEPARATOR } & Chi-square & Fishers exact & Chi-Square significance & $\begin{array}{l}\text { Fishers Exact } \\
\text { Sianificance }\end{array}$ \\
\hline \multirow[t]{3}{*}{ Pain on chewing } & \multirow[t]{3}{*}{ 4th hour } & 4.933 & 7.515 & .765 & .657 \\
\hline & & 2.121 & 2.083 & .684 & .657 \\
\hline & & 0.086 & .815 & .592 & .234 \\
\hline \multirow{3}{*}{ Pain perception } & \multirow[t]{3}{*}{ 24th hour } & 6.013 & 5.391 & .422 & .401 \\
\hline & & 2.121 & 2.083 & .518 & .5556 \\
\hline & & 6.473 & 6.832 & .594 & .570 \\
\hline \multirow[t]{6}{*}{ Pain affecting life } & \multirow[t]{3}{*}{ 4th day } & 2.281 & 2.520 & .684 & .657 \\
\hline & & 1.392 & 1.364 & .707 & .877 \\
\hline & & 4.415 & 4.372 & .572 & .669 \\
\hline & \multirow[t]{3}{*}{ 7th day } & 2.520 & 6.199 & .811 & .673 \\
\hline & & 0.086 & 0.069 & .769 & .478 \\
\hline & & 4.628 & 8.530 & .592 & .234 \\
\hline
\end{tabular}

TABLE 1: No statistically significant Association evident at any of the period of post Kesling separator placement

Table 2: There is significant association of elastomeric separators with pain perception and pain affecting life at 4th hour, 24th hour. Significant Association of Medication with the post separator placement pain also is significant at 4th and 24th hour of post separator placement.

\begin{tabular}{|c|c|c|c|c|c|c|}
\hline \multicolumn{2}{|c|}{ KESLING SEPARATOR } & Chi-square & Fishers exact & $\begin{array}{l}\text { Chi-Square } \\
\text { significance }\end{array}$ & $\begin{array}{l}\text { Fishers Exact } \\
\text { Significance }\end{array}$ & Medication \\
\hline \multirow[t]{3}{*}{ Pain on chewing } & \multirow[t]{3}{*}{ 4th hour } & 3.295 & 3.515 & .655 & .677 & \\
\hline & & 7.632 & 8.120 & $.005^{\star}$ & .644 & $0.000^{*}$ \\
\hline & & 4.907 & 2.772 & $.002^{\star}$ & $0.043^{*}$ & \\
\hline \multirow{3}{*}{ Pain perception } & \multirow[t]{3}{*}{ 24th hour } & 6.177 & 6.004 & 0.520 & .549 & \\
\hline & & 7.052 & 8.233 & .851 & .892 & $0.020 *$ \\
\hline & & 34.907 & 22.772 & $.002 *$ & $0.053^{*}$ & \\
\hline \multirow[t]{6}{*}{ Pain affecting life } & \multirow[t]{3}{*}{ 4th day } & 4.800 & 4.828 & .441 & .449 & \\
\hline & & 8.433 & 8.935 & .392 & .283 & \\
\hline & & 8.345 & 14.249 & .758 & .556 & \\
\hline & \multirow[t]{3}{*}{ 7th day } & 6.484 & 6.491 & .262 & .215 & \\
\hline & & 3.367 & 6.008 & .909 & .819 & \\
\hline & & 18.731 & 15.624 & 0.16 & 0.45 & \\
\hline
\end{tabular}

TABLE 2: *Significant Association of pain with separator evident at 4th and 24th hour post kesling separator placement 


\section{DISCUSSION}

The first step in the fixed orthodontic mechanotherapy after the patient counseling, consent and patient preparation is the placement of orthodontic separators for the band placement without the undesired periodontal and soft tissue injury. Angle and Case $^{21,22}$ initial attempts to separate the teeth was using the brass wire and the separating tape. Nowadays, Elastomeric donut separators and spring separators are much in use. However, the studies by Al Huwaizi et $\mathrm{Al}$ and Malagan MA et $\mathrm{al}^{23,24}$ have shown that the elastomeric separators cause greater amount of pain and discomfort and are dislodged easily.

Elastomeric separators have proven well in adolescent patients whose teeth are slightly mobile and restorations free. For the instances, where elastic separators cannot be placed due to the tight contacts, esp. in Adult patients, kesling separators have been advocated. Elastic separators have the tendency to break and distort in teeth with tight and broad contacts in adult patients. This not only causes pain but also brings about periodontal tissue damage. The recovery of the tissue takes around 20 hours with only $82 \%$ of baseline tightness of interdental tightness regained. This, however can be challenging for some during the initial days of orthodontic practice. ${ }^{25}$ This might lead to pain, which in turn can act to negatively reinforce the attitude of an orthodontic patient to the treatment. Metal separators like Kesling are easily fabricated within few minutes and have the advantage of easy insertion. They are also commercially available in different sizes of short, medium, long and extra-long.

Our results gathered from the 100 Orthodontic patients, showed that there is no association of Kesling Separator and pain on the 4th hour, $24 \mathrm{hrs}$, after the separator placement. 2nd 3rd 4th 5th 6th 7th day post separator placement also did not show significant association of Kesling separator with pain on chewing, pain affecting life and the overall pain perception. Whereas there was a significant association of elastomeric separators with pain affecting life and over all pain perception at 4th hour. Pain perception at the 24th hour post separator placement was also significantly associated with the elastomeric separator. Association of medication at 4 th and 24th hour post elastomeric separator placement was significantly associated.

Hence the separator placement before the start of the fixed Orthodontic treatment is a must. Regardless of the pain experienced; it is a mandatory procedure before the commencement of band placement. As an Orthodontist it is our responsibility to lessen the procedural pain and anxiety for the patient. Nevertheless, the use of buccal tubes can also be considered, as the studies have shown that there is a lesser degree of periodontal problem and there is no role of separator. However, frequent breakage of the appliance is evident making the Orthodontic treatment cumbersome and difficult. ${ }^{26}$ At the 7 th day, of the removal of the band, the teeth were well separated regardless of the separator used and teeth were easily banded without any hindrance. Elastomeric elastics are easily commercially available and the Kesling can be easily fabricated. Pain and consumption of medication are associated with the Elastomeric separator but not associated with the Kesling separator. Therefore for the ease of the patient, the use of the Kesling separator can be considered.

\section{CONCLUSION}

Orthodontics will require separation invariably. Separation can be painful and destructive. There is significant association of elastomeric separators with pain perception and pain affecting life at 4th hour, 24th hour. Significant Association of Medication with the post separator placement pain also is significant at 4th and 24th hour of post separator placement Medication may be required to make the procedure painless. It is our responsibility to make the procedure comfortable, and thus this study advocates the use of kesling metal separator. 


\section{REFERENCES}

1. Cureton SL. Headgear and pain. J Clin Orthod. 1994;28:525-30. [PubMed]

2. Needleman HL, Hoang CD, Allred E, Hertzberg J, Berde C. Reports of pain by children undergoing rapid palatal expansion. Pediatr Dent. 2000;22:221-6. [PubMed]

3. Firestone AR, Scheurer PA, Bürgin WB. Patients' anticipation of pain and pain-related side effects, and their perception of pain as a result of orthodontic treatment with fixed appliances. Eur J Orthod. 1999;21:387-96. [PubMed]

4. Sergl HG, Klages U, Zentner A. Pain and discomfort during orthodontic treatment: Causative factors and effects on compliance. Am J Orthod Dentofacial Orthop. 1998;114:684-91. [PubMed]

5. Abu Alhaija ES, Aldaikki A, Al-Omairi MK, Al-Khateeb SN. The relationship between personality traits, pain perception and attitude toward orthodontic treatment. Angle Orthod. 2010;80:1141-9. [PubMed]

6. Beck VJ, Farella M, Chandler NP, Kieser JA, Thomson WM. Factors associated with pain induced by orthodontic separators. J Oral Rehabil. 2014;41:282-8. [PubMed]

7. Krishnan V. Orthodontic pain: From causes to management - A review. Eur J Orthod. 2007;29:170-9. [PubMed]

8. Patel S, McGorray SP, Yezierski R, Fillingim R, Logan H, Wheeler TT. Effects of analgesics on orthodontic pain. Am J Orthod Dentofacial Orthop. 2011;139:e53-8. [PubMed]

9. Ngan P, Kess B, Wilson S. Perception of discomfort by patients undergoing orthodontic treatment. Am J Orthod Dentofacial Orthop. 1989;96:47-53. [PubMed]

10. Ngan P, Wilson S, Shanfeld J, Amini H. The effect of ibuprofen on the level of discomfort in patients undergoing orthodontic treatment Am J Orthod Dentofacial Orthop. 1994;106:88-95. [PubMed]

11. Bondemark L, Fredriksson K, Ilros S. Separation effect and perception of pain and discomfort from two types of orthodontic separators. World J Orthod. 2004;5:172-6. [PubMed]

12. Bergius M, Berggren U, Kiliaridis S. Experience of pain during an orthodontic procedure. Eur J Oral Sci. 2002;110:92-8. [PubMed]

13. Abhilasha Khanal, Li Hu, Lili Chen . (2015) Comparison of Expression Levels of RANKL and Interleukin-17A in Male and Female Orthodontic Patients With and Without Appliances .J Periodontics Restorative Dent 35:e28-e34. doi: 10.11607/prd.1886)

14. Ngan P1, Kess B, Wilson S. Perception of discomfort by patients undergoing orthodontic treatment.Am J Orthod Dentofacial Orthop. 1989 Jul;96(1):47-53

15. Wilson S, Ngan P, Kess B. Time course of the discomfort in young patients undergoing orthodontic treatment. Pediatr Dent. 1989 Jun;11(2):107-10.

16. Bergius M1, Berggren U, Kiliaridis S. Experience of pain during an orthodontic procedure. Eur J Oral Sci. 2002 Apr;110(2):92-8

17. Al-Balbeesi HO, Bin Huraib SM, AINahas NW, AlKawari HM, Abu-Amara AB, Vellappally S, Anil S. Pain and distress induced by elastomeric and spring separators in patients undergoing orthodontic treatment. J Int Soc Prev Community Dent. 2016 Nov-Dec;6(6):549-553. doi: 10.4103/2231-0762.195519

18. Kohli SS, Kohli VS. Effectiveness of piroxicam and ibuprofen premedication on orthodontic patients' pain experiences. Angle Orthod. 2011 Nov;81(6):1097-102. doi: 10.2319/022411-134.1. Epub 2011 Jun 6.

19. Polat O1, Karaman Al, Durmus E. Effects of preoperative ibuprofen and naproxen sodium on orthodontic pain. Angle Orthod. 2005 Sep;75(5):791-6.

20. Koritsánszky N1, Madléna M. [Pain and discomfort in orthodontic treatments. Literature review]. Fogorv Sz. 2011 Dec;104(4):117-21.

21. Angle EH. Treatment of malocclusion of the teeth. Philadelphia: White Dental Manufacturing; 1907.

22. Case CS. A practical treatise on the techniques and principles of dental orthopedia and prosthetic correction of cleft palate. Chicago: CS Case

23. Al Huwaizi AF. Comparison of the forces generated by steel, nickel titanium and elastomeric separators. J Bagh Coll Dent. 2008;20(1):78-86.

24. Malagan MA, Biswas PP, Muddaiah S, Reddy R, Shetty BK, Preetham J, et al. Comparison between efficacy of four different types of orthodontic separators. J Clin Diagn Res. 2014 Aug;8(8):ZC41-4

25. Vallakati A, Jyothikiran H, Ravi S, Patel P. Orthodontic Separators ñ A Systemic Review. JOHS 2014; 5(3),118-122

26. Saud $A$ et al. The effect of orthodontic bands or tubes upon periodontal status during the initial phase of orthodontic treatment. Saudi Dent J. 2015 Jul; 27(3): 120-124. 